\title{
TITLE: Mass Cultivation of C. turgidus and Oscillatoria sp. and Effective Harvesting of Biomass by Low-cost methods
}

\author{
Mohan N*a, Hanumantha Rao P, Ranjith Kumar R, and Sivasubramanian V \\ Vivekananda Institute of Algal Technology, \\ R. K. M. Vivekananda College, Chennai - 600 004, Tamil Nadu, India.
}

\author{
*Corresponding author at: \\ apresent address: \\ Centre for Advanced Studies in Botany, \\ University of Madras (Guindy campus), \\ Chennai - 600 025, \\ Tamil Nadu, India. \\ Mobile: +919710467079 \\ e-mail: jnmohan08@gmail.com
}




\begin{abstract}
The potential of microalgal biomasses for the production of biochemicals such as pigments, vitamins, antibiotics, polysaccharides, proteins, essential fatty acids, bio-flocculants, enzymes, etc. is well known. The purpose of this study was to cultivate two cyanobacterial species namely Chroococcus turgidus and Oscillatoria sp., isolated from industrial effluents, using a suitable growth medium in a large-scale High Rate Algal (HRA) pond. The biomolecules such as total protein, total carbohydrate and total lipid, and the pigments chlorophyll, phycobilins, $\beta$-carotene, were analysed at regular intervals during cultivation. In addition, the total bacterial cell numbers were enumerated during the study and their influence on algal growth was studied. The algal biomass was harvested by low-cost methods such as auto-flocculation and auto-floatation.
\end{abstract}

Key words: Chroococcus turgidus, Oscillatoria sp., mass cultivation, HRA pond, algalbacterial interaction, harvesting. 


\section{Introduction}

Cyanobacteria have a long history of existence and use and are the oldest known oxygenic organisms, which by their photosynthetic activity probably made a fundamental contribution to the development of the present oxygen-rich atmosphere. However, the commercialization has been triggered off only recently. Cyanobacteria constitute a vast potential resource, but only a few species have been studied intensively and used commercially. They are cultivated for use as a health food in the form of tablets and capsules and mostly species of Spirulina are mass cultivated globally (Lee, 1997). It is a non-toxic protein-rich product with various pharmacological properties (Belay et al, 1993; Fox 1996).

In general, cyanobacteria possess all the known phycobiliproteins (phycocyanin, phycoerythrin, phycoerythrocyanin and allophycocyanin). Among them, phycocyanin and phycoerythrin are commercially valuable; phycocyanin is a odourless, non-toxic blue powder and used for colouring candy, ice cream, dairy products and soft drinks (Cohen, 1986). Apart from these, a variety of carotenoids have important commercial uses. As carotenoids are nontoxic, they are desirable colouring agents in the food industry as well as vitamin A precursors (Bauernfeind, 1981). Cyanobacteria appear to be a rich source of new antiviral compounds (Sudararaman, 1992). Producing a suitable renewable fuel particularly employing biosystems is one of the priority research interests of the scientific community throughout the world. Cyanobacteria are also looked upon as a source of biofuels.

Basically, many of the metabolites produced by the organisms are in low amounts; moreover, there is no mass cultivation technology evolved for such potential cyanobacteria and in many cases, the method of industrial extraction is not optimized. Intensive research is thus warranted to understand many of the basic aspects pertaining to the production of a metabolite with the concurrent evolution of applied research towards the large-scale production of the product.

Therefore, the aim of this study was to cultivate two blue-green algae, C. turgidus and Oscillatoria sp., isolated from industrial effluents, using a suitable growth medium in a largescale High Rate Algal (HRA) pond and to harvest using low-cost methods. 


\section{Materials and methods}

\subsection{Organism}

Chroococus turgidus and Oscillatoria sp. were used for mass cultivation in an open algal pond, which were obtained from the Culture Collection of Vivekananda Institute of Algal Technology (VIAT), originally isolated from industrial effluents.

\subsection{Inoculum preparation and growth conditions}

The microalgae, C. turgidus and Oscillatoria sp. were inoculated in CFTRI medium and the culture was incubated for 15 days at $24 \pm 1{ }^{\circ} \mathrm{C}$ in a thermostatically controlled room and illuminated with cool inflorescence lamps (Phillips $40 \mathrm{~W}$, cool daylight $6500 \mathrm{~K}$ ) at an intensity of 2000 lux in a $12: 12 \mathrm{~h}$ light dark regime. The log-phase culture was used as feeder culture for outdoor cultivation.

\subsection{Outdoor cultivation of microalgae}

\subsubsection{Construction of HRA pond}

An outdoor algal pond was constructed with the wall thickness of $0.25 \mathrm{~m}$. The inner dimensions of the pond were such that the length was $3.65 \mathrm{~m}$ and the width was $2.3 \mathrm{~m}$. The depth of the pond was kept at $0.44 \mathrm{~m}$ keeping in mind the sufficient light penetration required for the growth of algae. A partition wall was constructed in the middle of the pond with a length of $2.46 \mathrm{~m}$ and a width of $0.11 \mathrm{~m}$. The floor was constructed with a slight slope on either side of the partition in the opposite direction to enable proper mixing of the culture. The inside of the pond was covered with ceramic tiles to avoid seepage of the medium into the wall. The tank was provided with a tap water connection for preparation of the medium and two outlets were provided so as to enable to clean the tank.

\subsection{Mass Cultivation of $C$. turgidus}

\subsubsection{Growth measurement}

Growth was measured throughout the study period by counting the cells using a haemocytometer (Neubauer, improved). 


\subsubsection{Analytical procedures}

Chlorophyll $a$ and chlorophyll $c$ was estimated using the extinction coefficients given by Jeffery and Humphrey (1975). Extraction and estimation of $\beta$-Carotene were performed according to the method of Shaish et al. (1992), total carbohydrates by Anthrone method of Loewus (1952), total protein according to Lowry et al. (1951) and total lipid content according to Bligh and Dyer (1959), Phycobilipigments were estimated from the extinction coefficients given by Bennett and Bogorad (1971). pH and conductivity were measured using digital $\mathrm{pH}$ and conductivity meters, respectively, throughout the study period. The bacterial cell numbers were measured by standard plate count method (pour plate technique).

\subsubsection{Harvesting of microalgae}

Autoflocculation method was performed for harvesting $C$. turgidus cells. For Oscillatoria sp., autofloatation and scooping of algal mats were carried out. The methods used for both the organisms were cost-effective and easy to perform.

\section{Results}

\subsection{Outdoor cultivation of $C$. turgidus}

One kilolitre of improvized CFTRI (1985) was prepared in the experimental HRA pond and $4 \mathrm{~L}$ of actively grown culture of $C$. turgidus was inoculated. It was cultured for 10 days with frequent samplings.

\subsubsection{Growth Measurement}

C. turgidus cell numbers of the samples collected during regular intervals were counted using a haemocytometer (Neubauer, improved). The growth pattern showed a gradual increase in cell numbers up to day 2 and thereafter steep increase from day 2 to day 5 . Then, the cell count was static for 2 days before coming down from the $7^{\text {th }}$ day (Fig. 1).

\subsubsection{Measurement of $\mathrm{pH}$ and conductivity}


$\mathrm{pH}$ and conductivity measurements of the culture were monitored on a daily basis and the results are given in Fig. 2. $\mathrm{pH}$ showed a steady increasing pattern up to day 6 and thereafter maintained at the same level. With respect to electrical conductivity, it was almost stable ranging between 5.3 and 5.8 millimhos/cm.

\subsubsection{Estimation of chlorophyll and $\beta$-carotene pigments}

Chlorophyll and $\beta$-carotenes were estimated spectrophotometrically for $C$. turgidus. Culture was sampled from the HRA pond on the $5^{\text {th }}$ day (the day on which the culture attained maximum growth). Among these pigments, $\beta$-carotene was the highest with $0.247 \mu \mathrm{g} / 10^{6}$ cells followed by Chlorophyll 'a' with $0.0149 \mu \mathrm{g} / 10^{6}$ cells and Chlorophyll 'C' with $0.0054 \mu \mathrm{g} / 10^{6}$ cells (Fig. 3).

\subsubsection{Estimation of phycobilins}

The water-soluble pigments were extracted from the $5^{\text {th }}$ day culture and quantified spectrophotometrically. The results showed that phycocyanin was more in $C$. turgidus, while allophycocyanin and phycoerythrin contents were lower compared with the former (Fig. 4).

\subsubsection{Total protein, carbohydrate and lipid contents of $C$. turgidus}

The $5^{\text {th }}$ day Chroococcus turgidus culture was analysed for protein, carbohydrate and lipid. When the results were compared, lipid content was found to be the highest and the carbohydrate and protein levels were low (Fig. 5).

\subsubsection{Bacterial study}

The bacterial growth was studied in outdoor culture and compared with that of the algae by monitoring the bacterial cell numbers. The bacterial cell count was high on day 1 when the algal cell count was low. As $C$. turgidus reached the logarithmic phase, there was a significant reduction in the number of bacterial cells. Again at the end of the study on day 7, when the algal numbers decreased, the bacterial numbers increased (Fig. 6). 


\subsection{Outdoor cultivation of Oscillatoria sp.}

Improvized CFTRI medium was prepared to the volume of $1 \mathrm{~kL}$ with a $\mathrm{pH}$ of 8.5 in the outdoor algal pond. Four litres of logarithmic-phase culture of Oscillatoria sp. was added, and allowed to grow for 10 days.

\subsubsection{Measurements of growth}

For monitoring the growth of Oscillatoria sp., dryweight was measured in the samples collected during regular intervals. The growth pattern showed gradual increase up to day 2 and thereafter steep increase from day 2 to day 5 . Then, the growth was static for 2 days before coming down from the $7^{\text {th }}$ day (Fig.7).

\subsubsection{Measurement of $\mathrm{pH}$ and conductivity}

$\mathrm{pH}$ and conductivity measurements were measured on a daily basis throughout the study and are shown in Fig. 8. From the figure, we can infer that the initial $\mathrm{pH}$ of 8.32 increased up to 8.96 on the $10^{\text {th }}$ day. Regarding electrical conductivity, the initial value of 5 millimhos/cm did not change up to 7 days and thereafter decreased abruptly to 3.5 millimhos $/ \mathrm{cm}$.

\subsubsection{Estimation of various pigments}

Chlorophyll, phycocyanin (C-PC), allophycocyanin (APC) and phycoerythrin (C-PE) were analysed spectrophotometrically after the 10-day period.

Among the pigments, $\beta$-carotene level was the highest with $3.0064 \mu \mathrm{g} / \mathrm{mg}$ dry weight followed by Chlorophyll 'a' with $1.2873 \mu \mathrm{g} / \mathrm{mg}$ dry weight (Fig. 9). Phycocyanin and chlorophyll ' $\mathrm{C}$ ' levels were the lowest with phycocyanin levels slightly more than the latter. Allophycocyanin and phycoerythrin were absent (Fig. 10).

\subsubsection{Estimation of total protein, carbohydrate and lipid}

The $10^{\text {th }}$ day pond sample were analysed for protein, carbohydrate, lipid contents . Carbohydrate content was the highest with $61.71 \mu \mathrm{g} / \mathrm{mg}$ dry weight followed by lipid and protein levels with 18.99 and $14.24 \mu \mathrm{g} / \mathrm{mg}$ dry weight, respectively (Fig. 11). 


\subsubsection{Bacterial study}

The total bacterial counts were measured in pond samples by standard plate count method on days 1, 5 and 10. The count on the initial day was $35 \times 10^{3}$ cells $/ \mathrm{ml}$ and increased to $70 \mathrm{x}$ $10^{3}$ cells $/ \mathrm{ml}$ on the $5^{\text {th }}$ day. Again, there was a reduction in bacterial numbers on the $10^{\text {th }}$ day with $10 \times 10^{3}$ cells/ml (Fig. 12).

\section{Discussion}

Little industrial effort in the mass production of microalgae is presently evident even after several decades of practising large-scale algal cultivation technology. A clear discrepancy exists between the well-recognized, commercial potentials of many microalgal species and the actual industrial developments; this could be attributed to the economic feasibility factor relatively due to low area outputs as well as the acceptability difficulties. In addition, the various problems associated with large-scale algal production are beyond microbiology and require cooperation with other scientific disciplines such as engineering, economics, medicine, toxicology, analytical chemistry, etc.

In the present investigation, technical feasibility of cultivating the microalgae, C. turgidus and Oscillatoria sp., in an open algal pond was evaluated. These two microalgae were harvested after 10 days because of their faster growth rates.

Various studies were conducted on these two blue-green algal systems during their growth. The growth curve pattern of these two micro-algae showed similar patterns. The growth of these two microalgae was maximum on the $5^{\text {th }}$ day. In Oscillatoria sp. the cell counts could not be measured and hence the dry weight method was carried out for growth measurements.

In the case of $\mathrm{pH}$ and conductivity study, both the organisms showed a steady increase in $\mathrm{pH}$ reaching around 9 at the end of the study. Electrical conductivity was also measured as this is an indirect indication of total dissolved solids (TDS).

Both the cultures were analysed for various parameters once in 5 days. In comparison, $\beta$ carotene and chlorophyll were higher than the phycobilins and this can be attributed to the high light (sunlight) conditions. Again in C. turgidus, lipid content was more when compared with proteins and carbohydrates and in turn proteins were more than carbohydrates.

In Oscillatoria sp., the concentration pattern of the chlorophylls and $\beta$-carotene was similar to that of $C$. turgidus. With regard to phycobilins, c-phycocyanin was the only pigment 
present in Oscillatoria sp. and the other two were absent. Cyanobacteria are known to occur in highly variable light conditions being subjected, not only to the daily light/dark cycle, but also to vertical mixing. The presence of very efficient mechanisms of photoacclimation explains their widespread distribution and success in different light condition (Millie et al., 1990). Composition of cultivation medium, cellular age and light intensity are the prime factors influencing chlorophyll and pigment content in Spirulina plantensis. Cultivation of S. platensis under less illumination showed higher biomass and chlorophyll content than under high illuminaion, suggesting an inverse proportion between light intensity and chlorophyll content. Moreover, the use of high light intensity in S. platensis cultivation can lead to two main effects: one is photoinhibition, decreasing the cellular growth rate, and photo-oxidation, with severe cell damage and, in extreme case, total loss of cultivation (Jensen and Knutsen, 1993; Vonshak et al., 1994). Although, photoinhibition usually occurs at light intensities above the saturation of photosynthetic rate, this phenomenon can be observed at light intensities below the saturation of the photosynthetic rate in cultivation under stress conditions such as low temperatures. Vonshak et al., (1988) demonstrated that high light intensities readily lead to photoinhibition in $S$. platensis, not only in the laboratory, but also in outdoor cultures, causing a loss as high as $30 \%$ of the potential production rate. Experiments by Vonshak and Guy (188) on outdoor cultures of Spirulina strains showed that they were sensitive to photoinhibition. It was shown by Jensen and Kutsen (1993) that both harmful effects like photoinhibition and photoxidation can be avoided if the pond light intensity and temperature can be controlled. In our study, total phycobilins were less than the chlorophylls and carotenoids, which can be attributed to the light factor.

Another important aspect related to algal pond ecology was studied i.e. the bacterial growth pattern was compared with the algal growth pattern in pond cultures of $C$. turgidus and Oscillatoria sp.. The bacterial numbers were lesser in C. turgidus cultures when compared with those in Oscillatoria sp. cultures, but the pattern was similar. This could be attributed to the faster growth rate of $C$. turgidus than that of Oscillatoria sp. Given the relatively low biomass obtained in microalgal cultivation systems due to the limit of light penetration (typically in the range of $1-5 \mathrm{~g} / \mathrm{L}$ ) and the small size of microalgal cells (typically in the range of 2-20 $\mu \mathrm{m}$ diameter), costs and energy consumption for biomass harvesting are of significant concern need to be addressed properly. Different technologies, including chemical flocculation (Knuckey et al., 2006), biological flocculation (Divakaran and pillai, 2002), filtration (Molina Grima et al., 
2003), centrifugation (Olaizola, 2003), and ultrasonicaton (Bosma et al., 2003) have been investigated for microalgal biomass harvesting. In general, chemical and biological flocculation require only low operating costs; however, they have the disadvantage of requiring long processing period and having the risk of bioreactive product decomposition. On the other hand, filtration, centrifugation and ultrasonic flocculation are more efficient but are costly, i.e. they require power. However, the methods used in this study, autoflocculation and autofloatation, are not only efficient but also cost-effective. Thus, the selection of cost-effective technologies for biomass harvesting and drying depends on the value of target products, the biomass concentration and the size of microalgal cells of interest.

In conclusion, efforts have been made to cultivate the microalgae in an open HRA pond and the biomasses were harvested by cost-effective methods. Effort has also been made in this work to study comprehensively the pros and cons of the outdoor cultivation of microalgae. The technical data presented in this paper are of relevance and value for further development.

\section{Acknowledgement}

We thank the Secretary and Principal of R.K.M. Vivekananda College, Mylapore, Chennai - 600004 , India, for providing us the necessary facilities.

\section{References:}

Bauernfeind, J. C. 1981. Carotenoids as Colourants and Vitamin A Precursors. London: Academic Press.

Belay, A., Ota, Y., Miyakawa, K. and Shimamatsu, H. 1993. Current knowledge on potential health benefits of spirulina. J. Appl. Phycol. 5: 235-241.

Bennett, A. and Bogorad, L. 1973. Complementary chromatic adaptations in filamentous Blue Green Algae. J. Cell Biol. 58: 419-435.

Bosma, R. VanSpronsen, W. A. Tramper, J. Wijffels, R. H. 2003. Ultrasound, a new separation technique to harvest microalgae. J. Appl. Phycol., 15 (2-3), 143-153.

Cohen, Z., 1986. 'Products form microalgae'. In: CRC Handbook of Microalgal Mass Culture. (Ed.). Richmond, A. Florida, USA: CRC Press, 421-454.s

Divakaran, R. Pillai, V. N. S. 2002. Flocculation of algae using chitosan. J.Appl.Phycol. 14 (5), 419-422.

Fox, R. D. 1996. Spirulina Production and Potential. Aix-en Provence, France: Edisud. 
Jeffrey, S.W. and Humphrey, G.F. 1975. New spectrophotometric equation for determining chlorophylls a, b, c and $c_{2}$ in higher plants, algae and natural phytoplankton. Biochem. Physiol. Pflanz., 167: 191-194.

Jensen, S. and Knusten, G. (1993). Influence of light and temperature on photoinhibition of photosynthesis in Spirulina plantensis. J. App. Phycol., 5: 495-504.

Knuckey, R. M.; Brown, M. R. Robert, R. Frampton, D.M.F. 2006. Production of microalgal concentrates by flocculation and their assessment as aquaculture feeds. Aquacult. Eng. 35(3), 300- 313 .

Lee, Y.K. 1997. Commercial production of microalgae in the Asia-Pacific rim. J. Appl. Phycol. 9: 403-411.

Lowry, L. H. Rosebrough, N. J., Farr, A.L. and Randall, R.J. 1951. Protein measurements with the folin-phenol reagent. J. Biol. Chem. 193: 265-275.

Millie, D.F. Ingram, D.A. Dionigi, C.P. 1990. Pigment and photosynthetic response of Oscillatoria agardhii (Cyanophyta) to photon fluex density and spectral quality, J. Phycol., 26: 660-666.

Molina Grima, E. Belarbi, E. H. Acien Fernandez, F. G. Robles Medina, A. Chisti, Y. 2007. Recovery of microalgal biomass and metabolites: Process options and economics. Biotechnol. Adv. 20 (7-8), 491-515.

Olaizola, M. Commercial development of microalgal biotechnol- ogy: From the test tube to the market place. Biomol. Eng., 20 (4-6), 459-466.

Shaish, A., Ben-Amotz, A. and Avron M. 1992. Biosynthesis of $\beta$ - carotene in Dunaliella. Methods in Enzymology, 213: 439-444.

Subramanian, G., Sekar, S. and Sampoornam, S. 1994. Biodegradation and utilization of organophosphorus pesticides by cyanobacteria Int. Biodeterior Biodegrada 33: 129-143.

Sundararaman, M. 1992. Intra and extracellular substances in marine cyanobacteria. Ph.D. Thesis, Bharathidasan University, Tiruchirappalli.

Venkataraman, G. S. 1981. 'Blue-green algae production for rice'. FAO Soil Bull. 46: 108.

Vonshak, A. and Guy, R. 1988. Photoinhibitionas a limiting factor in outdoor cultivation of Spirulina plantensis. In: Stadler, T., Mollion, J., Verdus, M.C., Karamanos, Y., Morvan, H. and Chiristiaen, D. (Eds), Algal Biotechnology, Elsevier Applied Science Publishers Ltd, Essex, New York. 365-370.

Vonshak, A. Torzillo, G. Tomaseli, L. 1994. Use of chlorophyll fluorescence to estimate the e ffect of photoinhibitionin outdoor cultures of Spirulina platensis, J.Appl. Phycol., 6: 3134.

Vonshak, A., Guy, R. and Guy, M. 1988. The response of the filamentous cyanobacterium Spirulina platensis to salt stress. Arch. Microbiol. 150: 417-420. 


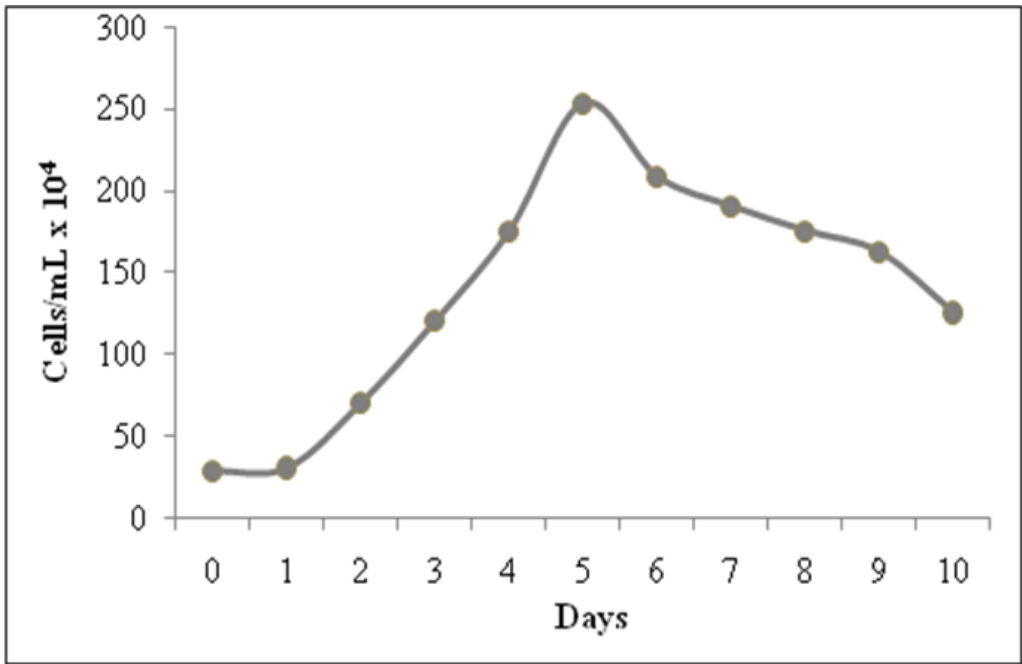

Fig.1. Grow th pattern of C. turgidus

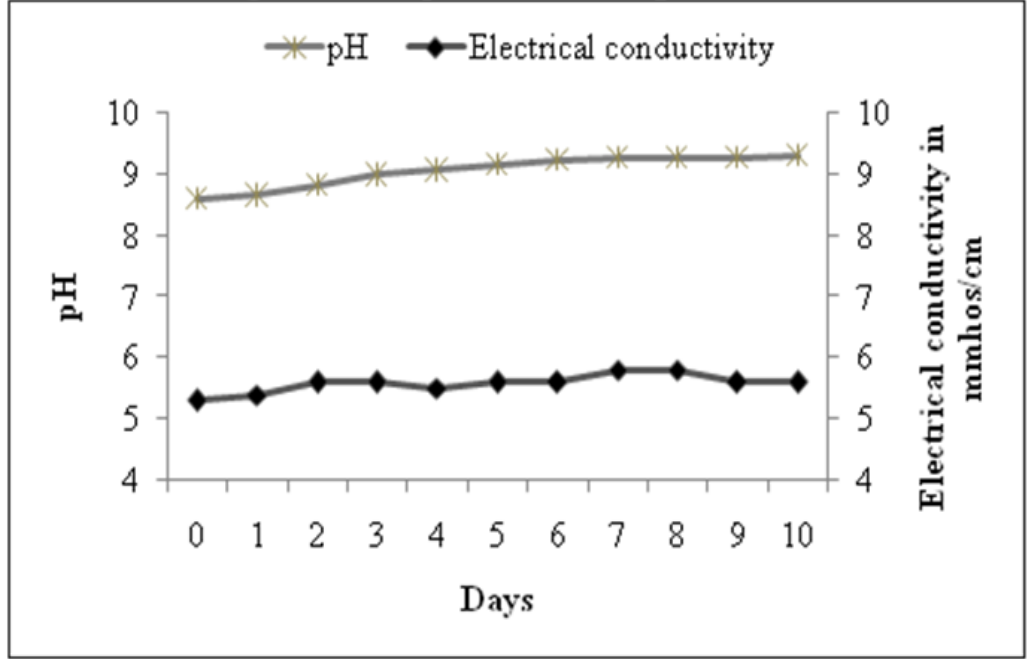

Fig.2. $\mathrm{pH}$ and Electrical conductivity of C. turgidus

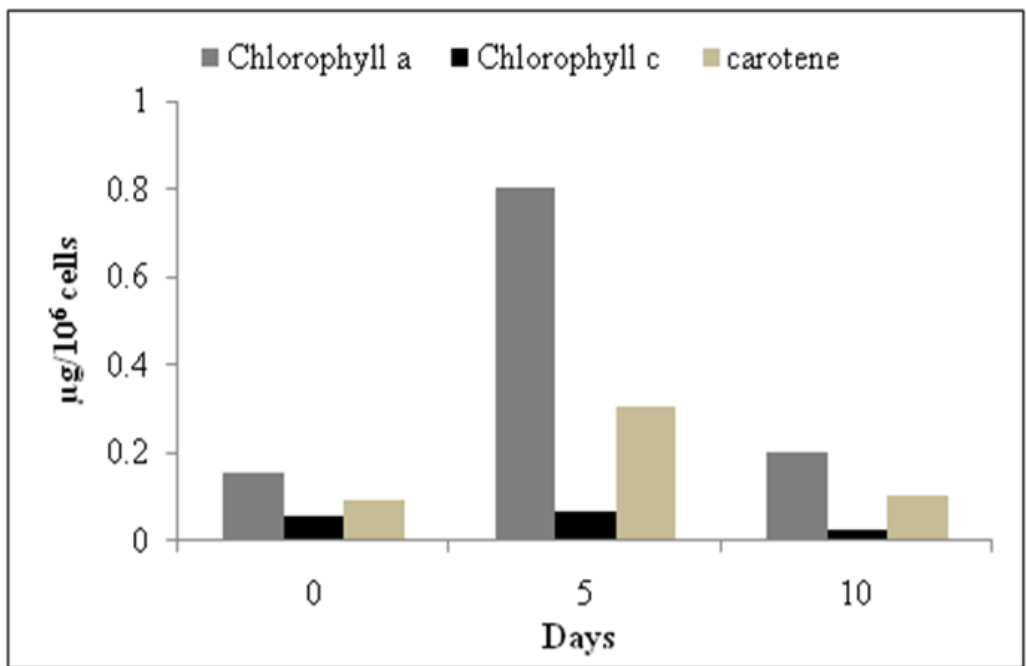

Fig.3. Chlor ophyll a, Chlorophyll $c$ and $\beta$-Carotene content of $C$. turgidus 


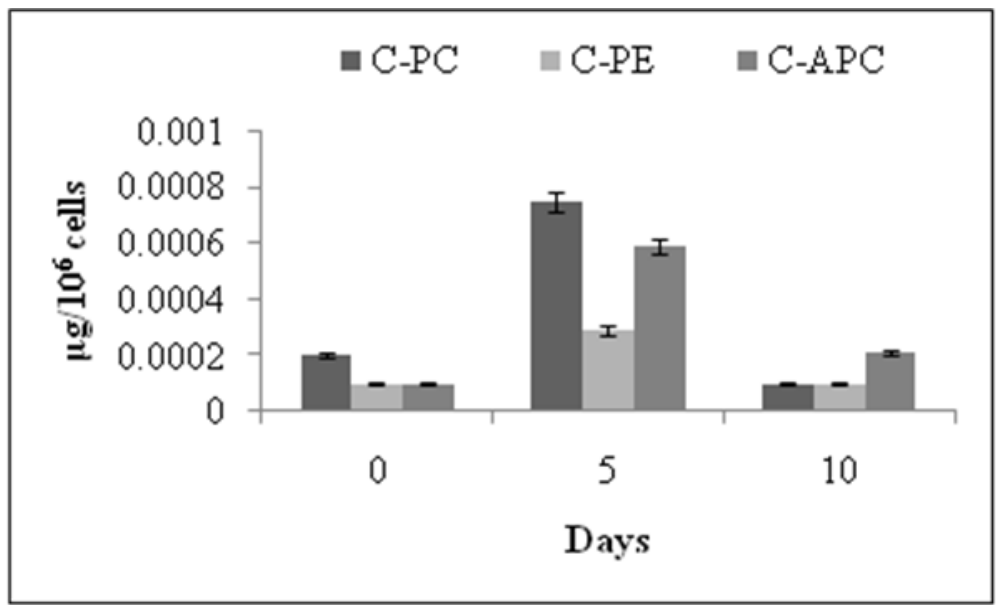

Fig.4. Phycobilins content of C.turgidus (C-PC C-Phycocyanin, C-PE C-Phycoerythrin, C-APC C-Allophycocyanin)

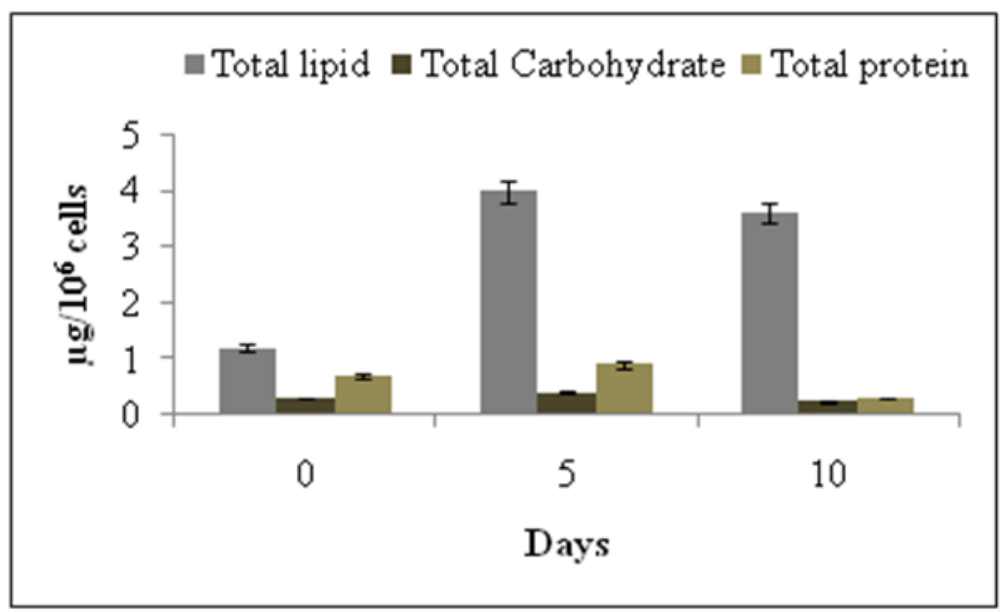

Fig.5. Total lipid,total carbohydrate and total protein content of C. turgidus

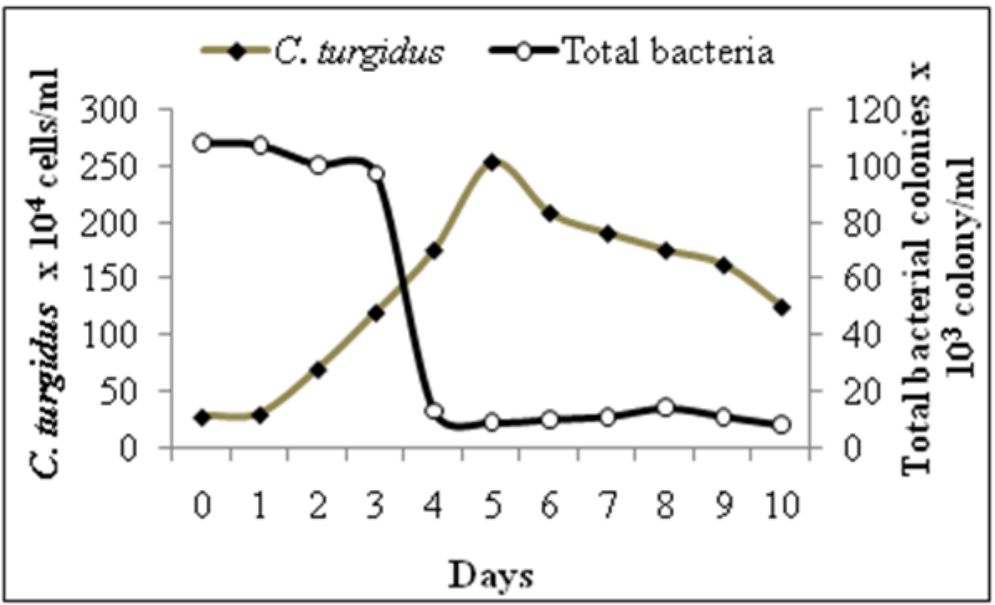

Fig.6. Bacterial growth pattern in C. turgidus 


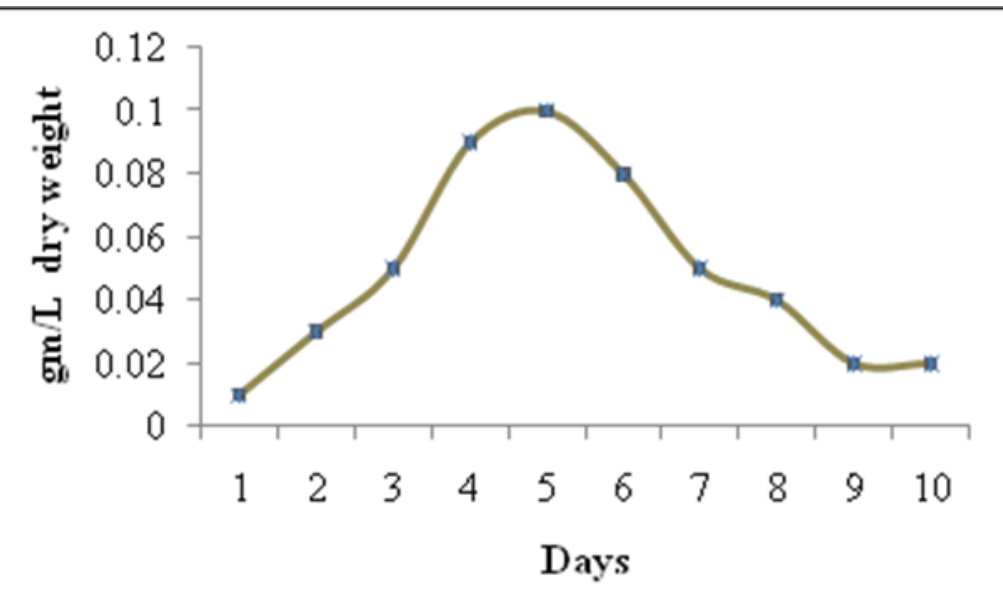

Fig.7. Growth pattern of Oscillatoria sp.

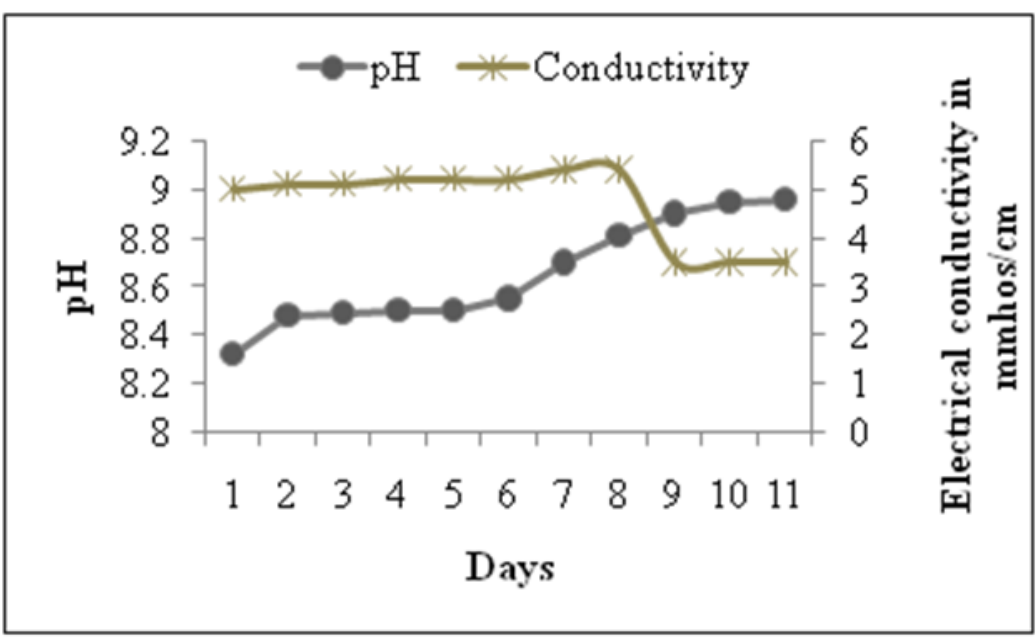

Fig.8. $\mathrm{pH}$ and Conductivity study on Oscillatoria sp.

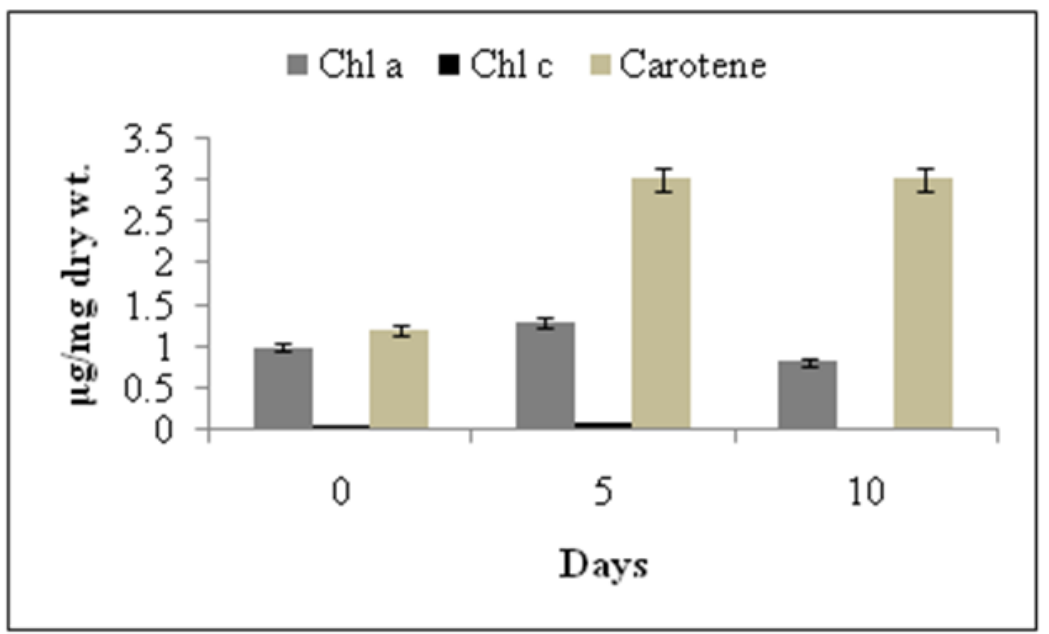

Fig.9. Chlorophyll and $\beta$-carotene content of Oscillatoria sp. 


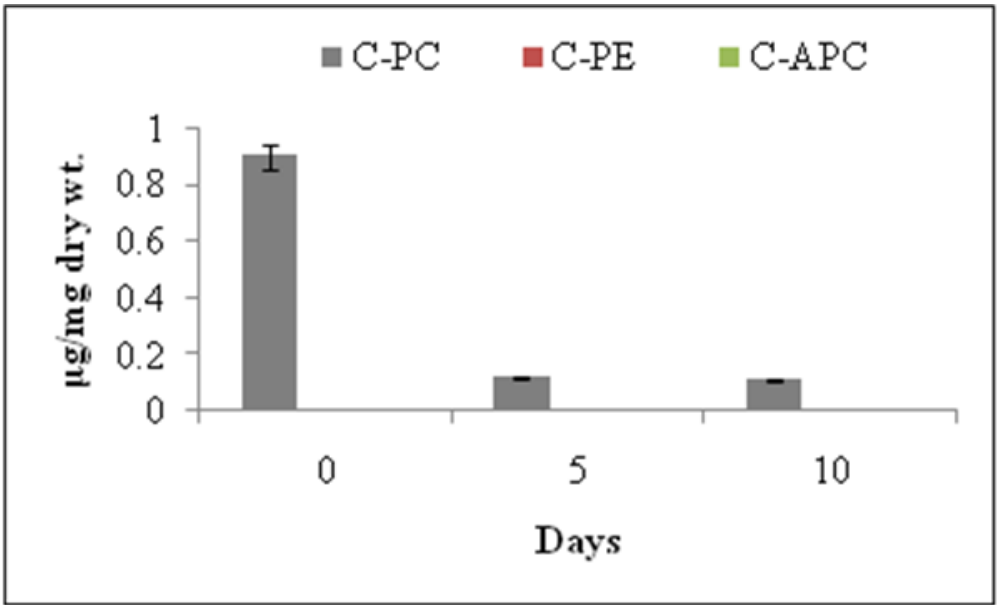

Fig. 10. Phycobilins content of Oscillatoria sp. (C-PC C-Phycocyanin, C-PE C-Phycoerythrin, C-APC C-Allophycocyanin)

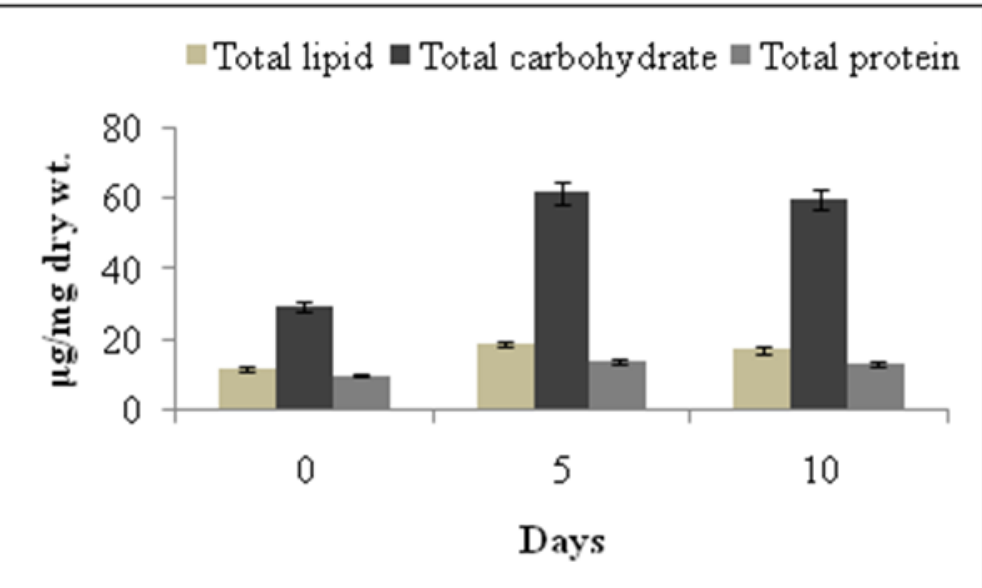

Fig.11. Total lipid, total carbohydrate and total protein content of Oscillatoria sp.

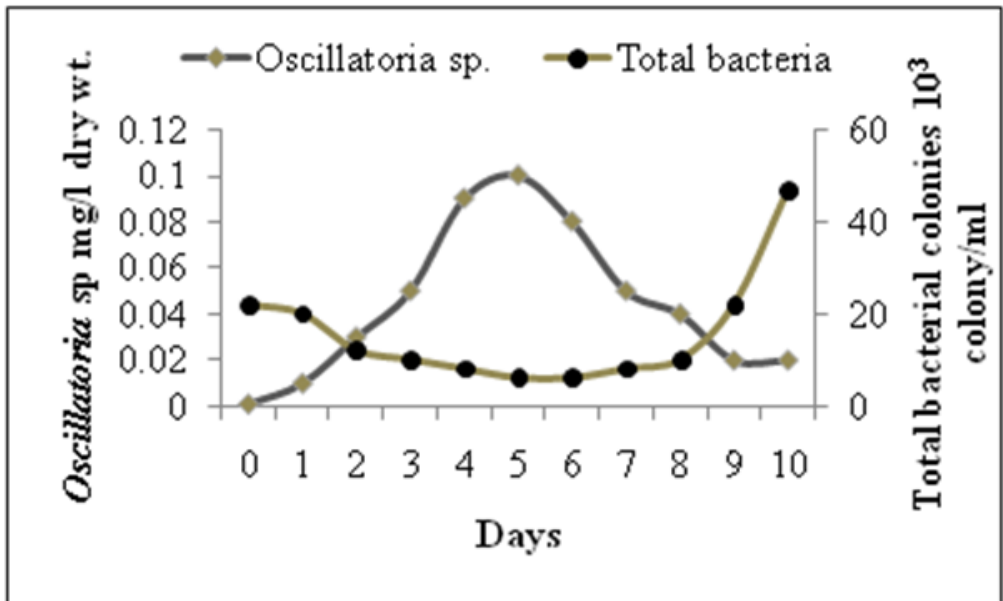

Fig.12. Bacterial growth pattern in Oscillatoria sp. 